4th International Scientific Conference SEC-IASR 2019,

Galati, Romania, 7th - 8th June, 2019

\title{
Models of Moral Education in Some Romanian Language and Literature Textbooks for Secondary School
}

\author{
Ana-Elena COSTANDACHE \\ https://doi.org/10.18662/lumproc/sec-iasr2019/14
}

How to cite: Costandache, A.-E. (2020). Models of Moral Education in Some Romanian Language and Literature Textbooks for Secondary School. In S. Marin \& P. Moisescu (vol. eds.), Lumen Proceedings: Vol. 12. 4th International Scientific Conference SEC-IASR 2019 (pp. 117-124). Iasi, Romania: LUMEN Publishing House. https://doi.org/10.18662/lumproc/seciasr2019/14 



\title{
Models of Moral Education in Some Romanian Language and Literature Textbooks for Secondary School
}

\author{
Ana-Elena COSTANDACHE 1
}

Abstract

The contemporary Romanian society lays stress on the individuals' problems, most specifically on the students who have to cope with the challenges of modern education, in both the home and school environment, in an attempt to gain an education according to relevant models of moral conduct. Education and self-education are closely related to the individuals' needs and willingness to become educated, through school (during the school years), family or media. The last one, however, attracts and distracts students more, as compared to books, which seem to be losing more and more ground and which should remain only a means of discovering one's own identity.

Reading generally represents a means of discovering and becoming aware of language models used by certain writers and of written communication models which contribute significantly to the students' shift from standardized, non-literary texts (which may be easily found in magazines, newspapers, etc.) to literary ones.

The present paper aims at bringing to the fore the importance of literary texts in the Romanian Language and Literature textbooks for secondary students from the point of view of the moral education models they provide.

Keywords: Education; literary text; textbook(s); moral value; literature.

1 “Dunărea de Jos” University, Galați, Romania, Elena.Costandache@,ugal.ro. 


\section{Introduction}

"To educate" and "to be educated" are the two main coordinates on which the contemporary Romanian society is based. In fact, education is a common right, one's openness to education commonly originating in the family and gradually moving to being cultivated, shaped and improved in school.

Education, from the perspective of moral values, envisages raising the individuals' receptiveness and awareness. The modern society brings to the fore the idea of dignity, culture, respect, equality of opportunity, all of these by forming and cultivating moral values.

Moral conduct originates in the family; it is shaped by school and completed by self-education. Moral education may be achieved by different means, reading literary texts being one of them. Reading is, for any individual, an efficient and effective means of education, training and understanding reality. In this respect, Alina Pamfil defined reading as an encounter with the spirits of the national culture, a royal-like variant of moral and civil education and of aesthetic values formation: "Shaping by reading literature means, undoubtedly, transforming the reader's vision of the world and of the people, a transformation which is mediated by the encounter with the structured and coherent perspectives offered and suggested by the writers." [our translation. Original text: ('Modelarea prin lectura literaturii înseamnă, fără îndoială, transformarea viziunii cititorului despre lume şi despre om, trasnformare mediată de întâlnirea cu perspectivele structurate şi coerente deschise de scriitori.”)] [1].

\section{Problem Statement}

The issue of education from the perspective of moral values is found and promoted in the Romanian language (approved) textbooks. These didactic materials include literary texts which provide, through the characters and events presented models of moral conduct, as well as counter-models. Under the circumstances, literary texts become education tools which contribute to the formation and development of students' personality, helping them discover their own identity. Literary texts are a source of exemplary moral conduct, as well as of numerous counter-examples, all of which being potentially exploitable sources of moral education. In this way, the Romanian literature classes become complementary to the classes of civic education, which aim at providing aesthetic and moral models to the students. 
Ana-Elena COSTANDACHE | Lumen Proceedings 12 | SEC-IASR 2019

\section{Research Questions/Aims of the research}

The idea of education in the spirit of promoting moral values is either not explicitly mentioned, or very briefly mentioned in the Romanian language and literature curriculum for secondary school, but such values are essential in the didactic activity.

Considering the objectives and learning activities included in the Romanian language and literature curriculum for the 5 th form (see Framework objective 3 - Developing the students ability to decode the written message, Reference objective 3.5.) the fact is mentioned that at the end of this form the students will be able to show curiosity and interest in the reading activity, adapting to the specific reading context.

This is not the case with the curricula for the 6th and 7 th forms which include no objectives regarding the students' moral education.

As regards the 8th form curriculum, the reference objective 3.3., part of the Framework objective 3 mentioned above, states that at the end of the 8th form students will be able to identify ethical and cultural values in texts, expressing their opinions and preferences. Practical activities are suggested in the form of exercises designed so as to help students identify and comment on the ethical and cultural elements traceable in literary texts and express their own attitude towards these elements.

Considering the aspects mentioned above, the present paper suggests an overview of the literary texts included in the Romanian Language and Literature Textbook for the 5th form (Humanitas Educational Publishing House 2008), Crişan A, Dobra S, Sâmihăian F. (coord.), with a view to identify some of the moral values highlighted. The fact is worth underlining that each unit in the textbook under discussion is an invitation to reading, which is, from our point of view, one of the strengths of this textbook.

1. Mircea Eliade's text, Cele dintâi lecturi (The first readings) [2] focuses on a young character who, being attracted to reading, seeks the most hidden places to delve into his passion.

Taking into consideration objective 3.5.previously mentioned, the text lays emphasis on the fundamental moral value of the reading; the character's need for reading is seen as a personal experience. Writing in the first person, singular number "betrays" the truthfulness of the narrated events. The textbook suggests a series of exercises meant to exploit the text, focussing on the idea of training and self-training through reading as an educational activity:

"Why did reading seem a new game to the child at first? 
What does he discover by reading?

What feelings does the child experience when entering the fascinating world of books? " [2: 15]

2. The poem O furnică $(A n A n t)$ by Tudor Arghezi awakens the students' interest in and sensitivity to the environment and protection of the tiny beings' world. The reading comprehension exercises regarding the exploitation of the text are various and concern, on the one hand, the world of the tiny beings and the human universe, raising the students' awareness of and attachment to this wonderful world, and the moral conduct, on the other.

"Select from the text the aspects by means of which the world of ants is compared to the human universe by the poet.

Identify, in the first two lines, the attributes which suggest that the ant would have the characteristics of a person.

Read the second line. Show what facts attributed to the ant highlights behaviour similar to the human one."

3. The poetic text Cărtile cu Apolodor (The Books with Apolodor) by Gellu Naum draws the readers' attention to the topic of united families, thus envisaging the students' education from the perspective of the moral values of society. The author lays emphasis on the character's love for the family members, and on its longing for home and for the loved ones, and brings to the fore the idea of true friendship, which allows for no differences or discrimination (Apolodor, a tenor circus penguin, becomes friends with a kangaroo and a lion). The exercises designed for exploiting the text and for expressing one's personal opinion are centred on the animal world and illustrate a series of emotions which are traditionally associated with the humans:

"Identify, in the three fragments, the sections which point to Apollodor's feelings.

Name, in one word, each of these feelings"..

4. The story Căprioara (The Deer) by Emil Gârleanu emphasizes the moral value of unconditioned love as illustrated by a deer's maternal love and self-sacrifice, for its baby. Some of the exercises suggested by authors of the textbook focus on the students' sensitivity and draw their attention to cultivating the feeling of pity:

"What exactly determines the deer's sense of pity for the baby?

Choose from the text the words which indicate this feeling." 
5. The literary fragment La cireşe (Stealing Cherries) from Ion Creangă's Memories from my childhood draws the students' attention to the moral value of assuming one's responsibility for one's actions. The author insists that, although childhood is the age of innocence, it has its moral values which need to be observed; stealing cherries is a counter-example and, from a moral point of view, the character's behaviour is not a moral model to the readers. below:

Some of the exercises which exploit moral conduct are illustrated

"Which of the characters is illustrative for the story told? cherries?

What is the neighbours' attitude towards the boy after his stealing

What does Nică do of this happening?

What are Nică's feelings after being punished? Does he repent or does he laugh at what happened?"

6. Ion Luca Caragiale's story Viæită... (The Visit ...) emphasizes the importance of the moral education received by children in the family and the fact that the parents' lack of moral criteria directly affects the children's conduct. The lack of respect for the other people, the use of inappropriate language, the lack of moral values cultivation in the family are traits which characterize the main character in Caragiale's story who, thus, becomes a counter-example of behaviour.

This text is exploited by a series of exercises aimed at encouraging students to express their opinion regarding the inappropriate behaviour of the main character, who, despite originating in a wealthy family, lacks the basic elements of moral education:

What attitude do Ionel's words suggest in the fragment...?

What can you say about the mother's opinions regarding children education in contrast with her only son's behaviour?

What is the difference between what Ionel wants to look like and the way he behaves? Who does he imitate in terms of way of dressing and behaviour?"

The supplementary textbook for the $7^{\text {th }}$ and $8^{\text {th }}$ forms (Limba si literature română. Pregătire completă pentru clasele a VII-a şi a VIII-a şi pentru evaluarea națională) includes further exercises meant to promote moral values such as: respect towards the others, family education, self-education, example and counter-example:

"Select two of Ionel's replies which highlight the disrespectful attitude towards the guest." [3] (Exercise 38) 
"Write a text (5-7 lines) and argue whether Ionel's behaviour corresponds to Mrs. Popescu's attitude towards education. [3: 47] (Exercise 55)

"Make a set of 5-6 rules which you think would ensure a successful child education. Explain, through relevant examples selected from the text, which of these rules are not observed by Mrs. Popescu." [3: 48] (Exercise 58)

7. The text Mihai Viteazul (Mihai the Brave) by Nicolae Bălcescu [2] brings to the fore the importance of observing and cultivating historical values. Knowing and appreciating the history of a country means respecting the corresponding nation, culture, and micro-universe. The fragment selected from this text emphasizes Mihai the Brave's historic personality. Such a text is illustrative for the history of the Romanians and the ruler's qualities represent an unquestionable model of moral values such as: bravery, honour, virtue, good organization of and love for the country and for the people. Some of the exercises highlighting the Romanian ruler's moral qualities are mentioned below:

"Which of Mihai the Brave's qualities are influenced by his feelings towards the people?

What elements in the text highlight the ruler-to-be's love for the country? " [2: 218]

8. The fairy-tale Prâslea cel voinic și merele de aur (Mighty Prâslea and the Golden Apples) by Petre Ispirescu is an illustrative literary example of the good and the evil as moral values. The students' attention is drawn to these two values, but also to the complementary ones because the main character is exemplary, developing constantly and remaining unaltered in terms of honesty, cleverness, courage, tenderness, moral values which contribute to his education and training. There are other characters in the story who are exponents of important moral values and the exercises selected by the textbook authors are relevant in this respect:

"Why is Prâslea always victorious?

What is the king's opinion about Prâslea at the beginning of the fairy tale? What about at the end? How does the main character evolve along the story?

What are Prâslea's qualities?

How does Prâslea manage to gain the king's trust and to convince him to leave the tree untouched for another year?

What are the main character's qualities and what is his attitude towards his brothers at the end of the story?

Why do the brothers want to see Prâslea hurt? 
Why do other characters in the story help Prâslea?

Why does Prâslea return to his father's kingdom as a simple man?

Why does the good always defeat the evil in fairy tales? "

9. The parable About the Lost Sheep, originating in the New Testament, the Holy Gospel of Luke (Sfânta Evanghelie după Luca) 15: 1-7, is based on promoting religious values such as: faith, obedience, the truth and the right way. Considering its specificity, the text is relevant from both a religious and a moral points of view, revealing a general truth by comparing it to a real fact (Jesus has mercy on sinners). The sheep lost from the rest of the flock symbolizes the sinful people, who lack faith and need to be helped. The fact is pointed out that help should be given only to those who really need it because God will rejoice more helping a sinner return to the right path than finding out that there exist ninety-nine righteous and faithful people.

The exercises in the textbook focus on moral aspects such as trusting the power of faith and bringing the sinners on the right track: sinners?

"Why do Pharisees and scribes disagree to Jesus' behaviour to

What message does this parable convey?"

\section{Conclusions}

The present paper has brought to the fore some of the elements of educational practice focused on promoting ethical, aesthetic and moral attitudes. In addition to achieving the framework and specific objectives included in the national curriculum, teachers should consider teaching the students moral values which may shape their personality. The literary texts included in the Romanian Language and Literature Textbook for the 5th form represents a real axiological support for moral education because they depict characters and situations which could be models to be followed or, on the contrary, negative examples to be rejected. In both cases, the moral values which find their foundation in the construction of literary characters are based on models specific to the real world.

Corpus

1. Cele dintâi lecturi (The first readings) - Mircea Eliade

2. O furnică (An Ant) - Tudor Arghezi 
3. Cärţile cu Apolodor (The Books with Apolodor) - Gellu Naum

4. Căprioara (The Deer) - Emil Gârleanu

5. Amintiri din copilărie (Memories from my childhood) - Ion Creangă, the paragraph „La cireşe” („Stealing Cherries”)

6. Virită... (The Visit ...) - Ion Luca Caragiale

7. Mihai Viteazul (Mibai the Brave) - Nicolae Bălcescu

8. Prâslea cel voinic şi merele de aur (Mighty Prâslea and the Golden Apples) Petre Ispirescu

9. Despre oaia pierdută (parabolă), Noul Testament, Sfânta Evanghelie după Luca, 15, 1-7 (About the Lost Sheep, the New Testament, the Holy Gospel of Luke) 15: $1-7$

\section{References}

[1] Pamfil A. Didactica literaturii. Reorientări. Bucureşti Ed. Art; 2016. 320 p.

[2] Crişan A, Dobra S, Sâmihăian F. (coord.). Limba şi literatura româna pentru clasa a V-a. Bucureşti: Ed. Humanitas Educațional [Romanian Language and Literature Textbook for the 5th form: Humanitas Educational Publishing House 2008]; 2008. 320 p.

[3] Cârstocea E, Columban M, Corcheş H, Kudor Do, Sfîrlea L. Pregătire completă pentru clasele a VII-a şi a VIII-a şi pentru evaluarea națională. Bucureşti: Art Grup Editorial; 2010. 416 p. 